\title{
Social, Cultural, and Temporal Dynamics of the AIDS Case Congregation: Early Years of the Epidemic
}

\begin{abstract}
Studies of legal decisionmaking have focused traditionally on how social influences, particularly the relative social standing of competing parties, affect case outcomes. More recently, sociolegal scholars have directed their attention to the significance of cultural categories in shaping case-based decisionmaking. We here examine how both social and cultural factors shape judicial decisions and their meanings for a "congregation" of court cases precipitated by the AIDS epidemic in the United States. Our logistic regression analysis of the opinions of 181 AIDS-related cases decided in the early years of the epidemic (1983-89) finds that two social factors, the relative social standing of parties and the types of claims brought to the court, and two cultural factors, the court's use of negative AIDS metaphors and references to individual rights, are significantly related to case outcome. Finally, in line with Galanter's (1990) notion that case congregations have histories that involve development and change over time, our temporal analysis reveals the emergence of two case congregations and suggests how each serves to bolster the legitimacy of the judiciary amidst social crisis.
\end{abstract}

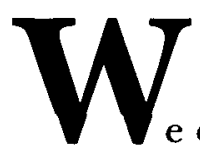

e explore here how the evolving social and cultural construction of a social problem shapes case processing over time. The social problem we focus on is AIDS, or HIV disease, and the case-processing context we concentrate on in this study is AIDSrelated litigation. In addition to tracking how social and cultural dynamics, external to the legal system, influence case outcomes, we recognize that the judiciary, as a powerful institution seeking to maintain its legitimacy, generates social and cultural messages of its own. Therefore, we also trace judicial invocation of rights in processing AIDS cases and treat rights as a cultural dynamic endogenous to the legal system which, in turn, influences the social and cultural construction of AIDS in the larger society.

This research was supported by a National Science Foundation Grant, Law and Social Science Program, grant no. SES-8908456. The authors' names appear in alphabetical order to reflect equal contributions. Address correspondence to Kriss Drass, Department of Criminal Justice, 4505 Maryland Parkway, Box 455009, Las Vegas, NV 89154-5009 (e-mail kadrass@nevada.edu). 
Studies of legal decisionmaking have focused traditionally on litigation and how social influences, particularly the relative social advantage of competing parties, affect case outcomes (e.g., Galanter 1974; Wheeler et al. 1987). More recently, sociolegal scholars have directed their attention to the claims transformation process (Canan et al. 1990), emphasizing the cultural dynamics, including competing discourses, at work in the manipulation of claims in courts of first resort and in mediation programs (e.g., Merry 1990; Merry \& Silbey 1984; Yngvesson 1988). Only a few studies, however, recognize the potential of the combined influence of social power and cultural forces on case processing and outcomes (e.g., Conley \& O'Barr 1990; Mather \& Yngvesson 1980-81). And even fewer studies focus on the social and cultural dynamics of case processing over time (see Galanter 1990; Stookey 1990).

Here we examine how both social and cultural dynamics shape the outcomes and meanings of a sample of court cases precipitated by the AIDS epidemic in the United States and decided between 1983 and 1989. These cases occurred in the early years of AIDS in the United States, or what some refer to as its first decade, 1981-90 (Odets 1994). From the initial reports of a new health threat until 1985, AIDS was depicted by public health officials and the media as a disease specific to gays (see Albert 1986; Shilts 1987). However, governmental, medical, and media reports shifted dramatically in the mid-1980s, indicating that the HIV virus was a threat to the "mainstream," white, heterosexual population (Rushing 1995:146-50). While these pronouncements did not establish that a "classic" epidemic was underway, with a widespread surge in death rates and a disruption of commerce and governmental operations (Durey 1979; Morris 1976), the shift in official discourse and media coverage of AIDS significantly heightened fear and the perception of personal risk among the general public. National polls conducted in 1985 and 1986 indicated that more than three-fourths of the respondents believed that AIDS was "now a threat to the general public," and as many as $40 \%$ said they were afraid of getting AIDS (Singer, Rogers, \& Corcoran 1987:586). In the context of an expanding perception of fear and personal threat, we examine cases in the formative years of judicial decisionmaking related to AIDS.

As a primary institution responsible for managing disputes arising from epidemics and disease scares, courts engage in the construction and promotion of a legal discourse which may incorporate other cultural ideas and discourses, such as the moral discourse of assigning blame for disease to marginalized groups in society (Rosenberg 1988; Sontag 1990). Integral to this legal discourse is the use of rights, which serve to legitimize judicial standing as an authoritative source for managing conflicts (Danelski 1984; Kairys 1982; Sarát 1984). "Rights talk," in turn, 
has become a staple of popular culture, influencing the legal consciousness of people (Merry 1990:5-6, 37-63) and encouraging individual and groups of disputants, and their supporters, to turn to strategic litigation to have their claims heard and acted on.

Using the opinions of 181 AIDS-related court cases decided between 1983 and 1989, we examine how the social construction of claimants, claims, and the meaning of HIV disease affects case outcomes. Also, we track how judges communicate their own messages about claims related to AIDS through their selective use of the language of rights to support their decisions. We realize that a sample of court cases for which opinions were written and reported cannot be treated as representative of all judicial decisions regarding AIDS issues (see Siegelman \& Donohue 1990; Songer 1988). Therefore, our findings must be viewed as exploratory. However, because our data are longitudinal, including some of the first AIDS-related cases to reach the court system, we have the unique opportunity to investigate how "case congregations," or groups of cases with shared features, develop a discernible career over time (Galanter 1990). To address these issues, we use recursive regression analysis (Griffin \& Isaac 1992) to model temporal changes in the ways social and cultural factors, external and internal to the legal process, are related to case outcomes and the manner in which decisions are communicated. Thus, while our findings are tentative, they are theoretically interesting and demonstrate the importance of integrating temporal context, through Galanter's (1990) concept of case congregation, into the study of judicial decisionmaking.

\section{Theoretical Foundations}

\section{Social Influences on Case Outcomes}

Black $(1976,1984,1989,1990)$ has devised a series of propositions addressing how similarities and differences in the social standings of conflicting parties (i.e., "the social structure of the case"; Black 1989:9) explain case outcomes. One of the most powerful predictors of outcomes, according to Black (1989), is the relative social status of the participants. When there is an imbalance in social status between parties, the law tends to work to the advantage of the higher-status party and to the disadvantage of the lower-status party. For example, in criminal cases, when people are accused of offending persons with higher social status, they are likely to be handled more severely than those accused of offending someone of lesser social status. In Black's terms (pp. 10-11), downward law (i.e., where the offender's social status is below the victim's) is greater than upward law (i.e., where the offender's social status is above the victim's). Wheeler 
et al. (1987) offer empirical evidence consistent with Black's general notion that differences in the social status of competing parties, defined in terms of size, resources, and power, influence case outcomes. Focusing on state supreme court rulings, they find that the more precisely social disparities can be delineated, "the larger the net advantage of stronger parties" (p. 443).

Besides varying in their relative social advantage, parties differ in terms of the claims for action they bring to a dispute. Spector and Kitsuse (1977) were among the first to treat claims as social constructions advanced by competing parties attempting to shape the meaning of a social problem favorable to their respective interests and ideologies. The logic of the social construction of social problems has been extended to analyze the claimsmaking activities of parties to agenda setting and program implementation specific to legislative processing of disputes (see Palumbo, Musheno, \& Hallett 1994; Schneider \& Ingram 1993).

We apply this perspective to claims-making activities related to judicial decisionmaking. Many institutions, including forprofit corporations (e.g., insurance companies), nonprofit corporations (e.g., blood banks), and public bureaucracies (e.g., correctional agencies, public schools) are affected by HIV disease. Claims-making activities coming from institutional spheres usually are constructed to reinforce the appropriateness of established institutional practices and routines. For example, insurance companies argue that screening people for the HIV virus is consistent with their fiduciary responsibilities to insurees; blood banks claim that restricting access to donor files is crucial to maintaining the blood supply; and correctional administrations claim that isolating inmates with HIV/AIDS is crucial to the maintenance of order. Generally, we label these and related constructions of AIDS-related claims as restrictive in that they seek to retain dominant patterns and ideas about social control and resource distribution.

Other parties, frequently but not always individuals, construct claims to alter established patterns of social control and resource distribution amidst changing events. For example, statewide public school authorities claim that children living with HIV should be mainstreamed with the "general" student population, challenging the authority of local school boards; inmates living with HIV claim that isolation is a violation of their rights to protection against cruel and unusual punishment; and the surviving partners of gay couples affected directly by AIDS assert their familial status against landlords who seek to evict them because they are not leaseholders or family members of leaseholders. Whether these constructions of claims come from individuals, groups, or institutions, we label them as expansionary because they attempt to block or change dominant regulatory regimes and/or distributional patterns (see Musheno, Gregware, \& Drass 1991). 


\section{Cultural Meanings and Judicial Decisions}

The recent expansion of schools of thought in the law and society movement (see Trubek \& Esser 1989) has generated an increasing emphasis on the relationship between culture and legal decisionmaking. Some scholars focus on everyday talk to identify cultural influences, particularly the style of speech (e.g., Conley \& O'Barr 1990), and specialized languages or discourses (Merry 1990) used by disputants and lower court officials to structure the contours of disputes and their management.

Critical legal scholars, focusing on judicial opinions, explore the normative assumptions that undergird case outcomes (Fischl 1987; Tushnet 1984; Unger 1986). They argue that legal doctrines and rights principles do not determine outcomes. Rather, judges shape human consciousness about social problems by using "rights talk" to legitimize a set of prevailing assumptions about human nature (e.g., pursue individual ends as long as doing so respects the ends of others), social beliefs (e.g., corporate profit as a social good), and distributional patterns (e.g., distribution of health resources based on the ability to pay). The job of the critical legal scholar is to uncover these normative orderings and relate their usage to case outcomes (Kelman 1987).

Our research draws from both of these schools of thought. Consistent with the scholarship on the claims transformation process, we recognize that disputants who are able to contextualize their claims in the form of prevailing ideas about rights have an edge over those who express their claims in terms of need, particularly material needs. Consistent with critical legal scholars, we view rights as the institutional language of the court used, in part, to establish and bolster the legitimacy of the judiciary as an institutional manager of social conflict. Therefore, we treat rights as a cultural artifact rather than as doctrine and seek to understand how they are used to support judicial decisionmaking about AIDS.

\section{Combined Influence of Social and Cultural Dynamics}

Only a few scholars have explored the combined influence of social and cultural factors in shaping case outcomes and their meanings. Conley and O'Barr (1990) discuss the class, racial, and gender distribution of "relational" and "rule-oriented" expressions of personal troubles and relate these speech styles to success in courts of first resort. In their case studies of dispute processing in non-Western and Western settings, Mather and Yngvesson (1980-81) agree that social power is manifested in the attributes of the disputants themselves and their supporting agents. At the same time, they emphasize the importance of language in the construction of the meaning of a dispute and how it 
should be managed. Specifically, they argue that "the language of law must be reckoned within its own terms: both rulers and the ruled must explicitly deal with it as a point of relevance in arguing cases and in legitimizing particular courses of action (Mather \& Yngvesson 1980-81:781; emphasis added).

Like these authors, we pay attention to the influences of both the relative status of competing parties and their respective constructions of claims. Also, we pay close attention to the expressive styles of judges, particularly whether and how the judiciary uses popular cultural portrayals of AIDS (e.g., as disease informed by medical science; as plague informed by previous disease scares), and people living with AIDS (e.g., as victims; as carriers of contagion), and rights talk, in framing their opinions.

\section{The Context of AIDS Litigation}

Galanter (1990) points to the importance of context and temporal sequencing in studying litigation in the United States. Specifically, he calls for a focus on case congregations or "groups of cases that are seen as a defined set that share common features, that are shaped by a common history, that are subject to shared contingencies, and that lean in a common future" ( $p$. 372). Also, he urges attention to the "career" of case congregations, or how the judiciary acts on these cases over time subject to external forces, and the unique logic of litigation strategy ( $p$. 373).

We treat AIDS court cases as a congregation with its own career. Casebooks specific to AIDS have been published (e.g., Jarvis et al. 1991), numerous AIDS litigation newsletters have appeared (e.g., ADS Litigation Newsletter), and legal guides have been created by public interest law firms to guide people living with HIV regarding their rights and duties (e.g., Burris et al. 1993).

The sociocultural dynamics of AIDS, particularly for the time period under investigation (1983-89), are similar to earlier epidemics. Yet, AIDS is distinct from epidemics in the 1800s and earlier in the United States and Europe, particularly with regard to its material consequences. ${ }^{1}$ Increases in death rates related to 17th-century plagues were sudden and dramatic, killing as much as $25 \%$ of the population (Sutherland 1972). Even 19th-century cholera scares struck suddenly, killing upwards of $10 \%$ of the

1 Fee and Fox (1992a:1-12) trace the role historians, including themselves, played in constructing AIDS as an epidemic that "belonged to history, a history that most had comfortably forgotten" (p. 2). Also, they argue that the epidemic and plague analogies were constructed for political advantage, particularly by AIDS activists. Rather than retaining the perspective that AIDS is an epidemic analogous to past epidemics, like plague and cholera, they assert that AIDS is more properly understood as a chronic disease (pp. 4-5). Their view ignores the political dynamics of the 1990s that led to the construction of AIDS as a chronic disease and disability, including the role of strategic litigation undertaken by gay rights activists and their allies (see Aiken \& Musheno 1994). If AIDS as epidemic is politically constructed, so is AIDS as disability. 
population living in the hardest-hit towns and villages of the British Isles (Morris 1976:12-13, 79-94). Equally significant, cholera epidemics of this period provoked institutional crisis, causing paralysis of commerce, collapse of government, and flight from populated areas. For example, the 1849 cholera epidemic in New York City prompted many to abandon their homes while commerce declined rapidly and public schools were converted into makeshift hospitals (Rosenberg 1962:108-10).

The material consequences of AIDS are not as significant or widespread. ${ }^{2}$ The National Research Council's Panel on Monitoring the Social Impact of the AIDS Epidemic undertook an intensive study of AIDS in New York City, one of the reported "epicenters" of the epidemic. The Panel claims that "the convergence of evidence shows that the HIV/AIDS epidemic is settling into spatially and socially isolated groups and possibly becoming endemic within them. ... [I]nstead of spreading out to the broad American population, ... HIV is concentrating in pools of persons who are caught in the 'synergism of plagues' " Jonsen \& Stryker 1993:7; also see Wallace 1989). They went on to note that only those institutions that serve highly marginalized people (e.g., inner city hospitals and public health clinics) are in crisis as a result of the AIDS epidemic.

But an epidemic is also a sociocultural phenomenon. As has been true of other epidemics, ${ }^{3}$ the early years of AIDS generated widespread fear (of contagion) and loathing (directed at those individuals who contracted the disease and groups reported to be at "high risk" for AIDS). Rushing (1995:158-59) provides the following account of the social dynamics of AIDS in the 1980s:

Overall, of course, the reactions to AIDS were not as extreme as to the earlier epidemics. . . But common elements in the reactions are clear. People avoided, ostracized, neglected, mistreated, or brutally beat people who had HIV-AIDS as well as members of high-risk groups, specifically gays. Some demanded that infected persons be quarantined. Demonstrations and

2 The material consequences of AIDS have been of epidemic proportions for subcultures of American society, including in the 1980s gay communities in cities like New York, San Francisco, and Chicago, and for a number of illicit drug user subcultures. For an account of the levels of infection in drug subcultures of major American cities, see Inciardi (1992). Also, the material consequences of earlier epidemics, including death rates, governmental breakdown, and disruption of commerce, were not uniform across populations or geographical areas. For example, Morris (1976) documents the geographical and class variations in the cholera epidemic of 1832 in the British Isles. Also, he indicates that the trade slump attributed to cholera was more probably caused by overproduction and quarantine regulations (p. 122).

3 Fear and loathing are central traits of the epidemics of the 17 th and 18 th centuries in Europe and the United States. For example, the threat of cholera to Britain in 1831 generated "choleraphobia ..., a wave of general apprehension" (Durey 1979:134) as newspapers began to report that the disease had reached the Baltic ports. In his study of the cholera outbreaks of the 1800s in the United States, Rosenberg (1962:40) depicts the public discourse of cholera, including the widely held view that it was "God's Justice, . . . a scourge not of mankind but of the sinner." 
moblike actions bordering on riots by high-risk groups took place. Scapegoats were found. . . The similarities are too great to dismiss.

Moreover, AIDS appeared at a time when scientific medicine had reached an exalted status, and infectious diseases were regarded by medical experts and citizens alike as past history (Dowling 1977). AIDS fissured the high status of scientific medicine and shattered the public's sense of security and apathy regarding such diseases (Rushing 1995:147-48).

Disease scares, like AIDS, evoke conflicts within and across institutional spheres. Courts in the United States have been involved in managing disputes related to all modern disease scares and epidemics, including syphilis, cholera, and bubonic plague (Bayer 1989). Historically, legislative bodies and state agencies have responded to the social tensions revealed by disease scares by assigning blame to marginalized groups viewed as a threat to the established order (Nelkin \& Gilman 1988; Rosenberg 1988). This focus on marginalized people as surrogates for transmissibility threatening the "mainstream" population provides a target for punitive action by the state while affirming dominant social institutions, power relationships, and established cultural norms amidst crisis (generally see Rosenberg 1988).

The prevailing historical response of the U.S. courts to disease scares and epidemics supports the sociolegal theme that the judiciary operates routinely to legitimize the dominant social and cultural order (Hunt 1993). In managing disputes related to disease scares, the courts have generally accepted the designation of marginalized others as carriers of disease, deferred to legislative and public health authorities, and endorsed the use of punitive measures without scrutinizing their effectiveness or justness (Gostin 1987).

At the same time, counter-tendencies to judicial legitimation of the dominant social and cultural construction of disease scares can be found in court opinions. As early as 1896 , judges signaled an interest in scrutinizing medical and scientific evidence to sort out the effectiveness of state measures to control disease scares (see Smith v. Emery 1896). Also, McClain (1988) details the importance of collective action in combination with legal strategy to counter the repression associated with the bubonic plague scare of 1900 in San Francisco. He identifies sociolegal conditions that enabled Chinese Americans, a marginalized community labeled as carriers of plague, to block draconian control measures and gain judicial support for expansionary claims. Specifically, he points to the organizational strengths of the Chinese community, its ability to garner strategic resources, and the skills of its lawyers to shop for and effectively press test cases before a federal district court judge who, in turn, scrutinized state measures with regard to both effectiveness and fairness. 
We see some parallels between the response of the Chinese American community to the bubonic plague scare and the response of the gay community to HIV disease. In the late 1970s and early 1980s, the United States was ignorant of AIDS, a lethal disease already infecting its population (Shilts 1987). Once the disease was identified in this country, it was associated first with the gay community. As the disease emerged in the public eye, much attention was paid to the social group affected by the disease instead of the disease itself. It was as if becoming infected with the disease was simply a result of being gay. Gays became surrogates for transmissibility, and instead of the disease being contagious, gays were contagious.

The gay community mobilized in response to the needsbased claims of gays infected with HIV and in recognition of the social threat posed to gays by the early construction of HIV as a gay disease (Cruikshank 1992:182-89; Padgug \& Oppenheimer 1992). Gay rights litigators, skilled in strategic litigation, began representing people living with HIV in contestations with state agencies and businesses. Therefore, the organizational strengths and strategic resources of the gay community provided litigious people living with HIV with strong, supporting agents and in some cases sparked AIDS-related litigation as test cases intended to advance gay rights (Hollibaugh, Karp, \& Taylor 1988:127-42; Jonsen \& Stryker 1993:232-33).

Also, an AIDS activist movement emerged out of the gay community that combined direct action with expressive politics (Gamson 1989). With its ranks filled by people from the arts and entertainment industry, groups like ACT-UP conducted "actions" (i.e., demonstrations well suited to mass-mediated imagery) and targeted institutions that were sources of AIDS stereotyping (see Crimp 1988a:3-17). Their actions, in turn, sensitized the gay rights movement to the power of language and cultural representation to influence litigation and, at the same time, sparked an ongoing debate in the gay activist community about the efficacy of a political struggle committed to a discourse of rights (Ingrassia 1993).

Therefore, we expect the congregation of AIDS-related cases to generate a strong social and cultural dynamic. Judges, like other case-based decisionmakers, bring order to case congregations by choosing among competing analogies or classification systems to reach and justify decisions (Drass \& Spencer 1987; Levi 1949). We argue that a combination of social and cultural conditions, temporally grounded and specific to a social "sphere" or social problem area, more than doctrine shape the contours of such classification systems (Laumann \& Knoke 1987; Smith 1988) and establish the fundamental parameters of a case congregation (Galanter 1990). In this analysis, we identify the social and cultural factors associated with wins for plaintiffs and docu- 
ment changes in these relationships that emerge as this congregation of cases matures.

To do this, we focus on four basic questions. First, what is the power relationship between parties in a case? We anticipate that those parties with social advantage prevail, although the relative domination over those less powerful may decline over time. For example, the relative advantage of dominant parties may decrease due to increasing third-party support for individuals living with HIV; public responsiveness to attempts by medical and public health experts and advocacy groups to change the cultural characterizations of AIDS; and from what Galanter (1990) describes as the life process of case congregations, high initial success by dominant parties followed by increasing success of plaintiffs who organize and identify the most eligible avenues for success.

Second, what claims do the parties bring to the court? We expect that a party's use of restrictive claims, which offer justifications for maintaining existing patterns of regulation and distribution, will have a positive and significant impact on that party's success relative to those who make expansionary claims oriented toward social change.

Third, what is the perspective of the judicial decisionmaker toward AIDS and toward people living with HIV? We anticipate that judicial ideology about AIDS runs consistent with the popular cultural perspective that treats people differently based on how they contracted the virus and that associates contagion with lifestyles. Therefore, we expect to observe a negative relationship between evidence of this perspective in the opinions and wins for plaintiffs. As the case congregation matures, this moral construction of AIDS may be less evident in the opinions, which would be consistent with the increased prevalence of scientific discourse about AIDS in the popular culture.

Fourth, when are rights cited and used to legitimize judicial rulings related to AIDS? We treat rights as the unique language that courts use to communicate their own messages about the claims and the claims makers engaged in AIDS-related disputes. Gay activist lawyers have cast the claims-making activities of white gay people living with HIV as rights-grounded and related their claims to the analogous claims of disabled people experiencing discrimination in the workplace and in housing (see Aiken \& Musheno 1994). We anticipate that judges are likely to invoke rights selectively, for example, drawing on rights to legitimize decisions in which claims about familiar forms of discrimination are brought forward by plaintiffs represented by strong gay and civil liberties interests trying to shape the contours of antidiscrimination doctrine in the United States. Therefore, we expect to find a positive relationship between the use of rights talk by judges and wins for plaintiffs. 


\section{Data and Variables}

The data for this study are 181 written judicial opinions submitted for publication, where principals in the cases were living with HIV and/or where a primary issue before the court was related to AIDS. ${ }^{4}$ All the cases were decided between 1983 and 1989. Like litigation newsletters on AIDS and legal texts dedicated to AIDS law, these cases cut across many traditional legal categories (e.g., criminal, tort). After describing the cases and the operationalization of the variables, we analyze the complete congregation and then turn to the analysis of whether and how the congregation changes over time. Throughout the analysis, we elaborate our findings by referencing particular cases that represent the sociocultural dynamics of the congregation.

Many of the cases focused on discrimination toward children infected with HIV. In Ray v. School District (1987), three hemophiliac boys (aged 10,9, and 8) tested positive for HIV after receiving blood-clotting treatments. When their parents voluntarily disclosed their HIV status to school officials, the boys were excluded from regular classrooms and offered homebound instruction. Backed by public health officials, their parents requested regular classroom instruction, arguing that the Ray children were being irreparably harmed by their exclusion. They pointed to the severe emotional distress being experienced by the children, including feelings of anxiety and rejection manifested by such episodes as bed wetting, crying, and nightmares, as well as the educational deficiencies attributable to exclusion from regular comprehensive educational programs. School officials responded by focusing on the potential harm the Ray children posed to other children due to their HIV/hemophiliac status, producing physician testimony which recommended "goggles, gloves, and gowns" whenever anyone dealt with the Ray children.

There were also a wide variety of cases that focused on discrimination toward adults infected with HIV or diagnosed with AIDS. For example, in Raytheon Co. v. Fair Employment $\mathcal{E}$ Housing Commission (1989), an inspector named John Chadbourne, who worked in a Raytheon facility, was fired from his job after being diagnosed with AIDS. After a brief hospitalization, Chadbourne's treating physician, Raytheon's occupational nurse, Raytheon's medical consultant, and the director of the area Communicable

4 A total of 189 cases were identified by cross-referencing two national legal data bases. These data bases select their cases based on written judicial opinions submitted for publication. While not all submitted cases are published, the "slip" opinion for each submitted case remains in the data base. We included all AIDS-related cases, both published and unpublished, in this study, with the stipulation that the written opinion must contain sufficient text (usually a paragraph or two) for evaluation. Subsequently, 8 cases were dropped due to missing data on some of the variables used in this analysis. Of the remaining 181 cases used in the analysis, $59 \%$ were decided by trial courts and $41 \%$ were decided by appellate courts. 
Disease Control Center all recommended that he return to work, asserting that he was fully capable of performing his work with little if any risk of infecting others with AIDS. Raytheon's medical director agreed that Chadbourne "could return to his job" but recommended that he not be reinstated and that management "beg for time." This recommendation was followed by management, which asserted a potential health risk to co-workers. This failure to reinstate was "devastating and distressing" to Chadbourne, who died before the court eventually ruled in his favor.

A number of cases focused on the breadth of governmental control over those incarcerated. For example, in Doe v. Coughlin (1986), an inmate who had been previously allowed conjugal visits with his wife had been denied further visits due to his AIDS diagnosis. Petitioner's arguments focused on the individual, specifically on such issues as marital privacy and equal protection of the law, and simply asserting that he could and would practice "safe sex." The court's response focused on the power of the state to grant or withhold privileges and the need for the state to control the spread of AIDS.

Many similar cases focused on the limits of state action in criminal proceedings, such as in Shelvin v. Lykos (1987), where the state sought mandatory HIV testing for a defendant who had been charged with two counts of aggravated sexual assault. The court framed the competing interests as "the inviolability of the individual" under the Fifth and Fourteenth Amendments versus the "best interests of society," as if those interests are necessarily separate. Actually there were other individuals making claims in this case; "the parents of the alleged victims were concerned" about the defendant's HIV status as was the local sheriff, representing his jail staff and other inmates who had contact with the defendant. Stating that "this is a health issue," the court ordered the test and disclosure to jail officials and to alleged victims and their families.

Transmission of AIDS engendered numerous suits seeking to assign liability. In McKee v. Miles Laboratories (1987), the widow of a person who had died of AIDS sought to impose liability on a blood products manufacturer for transmission of the disease. While citing the "terrible personal tragedy that David McKee's struggle with AIDS must have been for the McKee family," the court, as have most courts dealing with this issue, denied petitioner's claims by focusing on state laws which protected blood suppliers from liability.

In the name of AIDS prevention, many attempts were made to regulate sexuality. For example, in Suburban Video v. City of Delafield (1988), strict licensing and open-booth requirements were imposed by the city on an adult-oriented video rental and viewing store. The store owners asserted claims of free speech and privacy, arguing that concern over the spread of AIDS was 
being used as a pretext to curtail unwanted sexual activity. The city argued in response that some peep-show patrons would be less likely to engage in anonymous sexual activity in open areas, making such restrictions rationally related to legitimate concerns over the spread of AIDS.

To summarize: the plaintiffs in these cases are primarily individuals $(68 \%)$ but government $(21 \%)$ and business $(7 \%)$ are also active. In contrast, $47 \%$ of the defendants are governments, $32 \%$ are businesses, and $20 \%$ are individuals. The issues in these cases reflect the predominant interests of individual plaintiffs. Discrimination $(27 \%)$, inmate grievances $(17 \%)$, conflicts over confidentiality and testing ( $16 \%)$, and tort claims related to alleged negligence in the blood supply (15\%) are the most prevalent issue areas. Government initiation of court procedures primarily involves criminal prosecutions ( $11 \%)$, although some educational, social service, and civil rights agencies are also active with their respective issues. Noteworthy are the number of cases involving the regulation of sexuality $(6 \%)$. Here, government is initiating or individuals or businesses are protesting the imposition of state controls on sexual behavior.

Because our sample is limited to opinions submitted for publication, our findings are not necessarily representative of all cases involving AIDS. In fact, several studies have shown the possibility of significant differences between published and unpublished federal trial court decisions, with the presence and level of the differences dependent on the legal area and case factors analyzed (Siegelman \& Donohue 1990; Songer 1988). Siegelman and Donohue, who focused on employment discrimination, noted several differences between published and unpublished cases: the kinds of discrimination being complained about, the laws allegedly being violated, and the outcome of the litigation. Since we have no data about the number or kind of unreported AIDS cases during this period, we cannot determine whether, or in what ways, our cases may differ from them.

While acknowledging the limitations associated with the use of reported cases, we believe that our analysis still has merit and can lead to important insights given the specific goals of our study. We are interested in understanding the social and cultural dynamics of a particular case congregation in the early years of its development. In defining this concept, Galanter (1990:372) argues that cases within a congregation not only have shared features but also influence one another. Thus, while these 181 cases may not be representative of all decisions made by judges during this period, we believe that published or reported decisions reflect the key policymaking judgments of courts (see Rowland \& Carp 1996:21) and that by their public dissemination, these cases potentially affect each other and the general development of this case congregation. Further, we present an approach to the longi- 
tudinal analysis of court cases that has potential for future research in this area. While limited in generalizability, our sample of cases is sufficiently varied in terms of outcomes, social, and cultural characteristics to be useful for this goal.

Our variables, all dichotomies, were constructed from the opinions of the cases. ${ }^{5}$ Case outcome, the dependent variable in all of our analyses, was coded 1 if the plaintiff won and 0 if the defendant won. ${ }^{6}$ Building on the work of Black (1976), Galanter (1974), and Wheeler et al. (1987), we recorded which party (plaintiff $=1$, defendant $=0$ ) had a superior social standing relative to the other based on size and role advantage. ${ }^{7}$ We used two variables to measure the types of claims brought before the court. The first indicates a case in which the plaintiff's claim is expansionary, demanding some type of social change, while the defendant's claim is restrictive, supporting the status quo. The second indicates the reversal of these positions (plaintiff's claim is restrictive, defendant's claim is expansionary). ${ }^{8}$ Cases in which parties presented similar claims, such as retaining child custody

5 Coding of the opinions was performed by three individuals with legal training (Gregware and two second-year law students). A codebook, specifying operational definitions for all variables, was developed initially in conference by a research team that included the coders. These definitions were then adjusted by the coders as they applied them to a set of test cases. After final consensus was reached on each operational definition, ten additional opinions were coded by each coder. If all three coders agreed in nine of ten cases, the operational definition of the variable was considered reliable and subsequently applied by a single coder. The remaining variables were coded by at least two coders and any discrepancies resolved by discussion and consensus among the coders. Any unresolved coding decisions were taken to the larger research team for final resolution.

6 In any legal case, the court may address a variety of issues. In such multiple-issue cases, we listed the issues decided by the court and compared these to the claims of the parties. The extent to which the decisions on multiple issues affected the central claims of each party determined whether we coded a party as a relative winner or a loser for the case in question.

7 For example, a federal agency or a major corporation would have superior resources relative to a community school board or a local hospital. Role advantage involves situations in which one party has coercive powers over the other, such as regulator/regulatee or correctional administrator/inmate, or where there are differences in social authority, such as doctor/patient.

8 To identify the nature of each party's sociolegal claim, coders first used the basic facts of the case to categorize the domain of the dispute (e.g., torts, criminal process, family process) and the legal claim asserted by each party (e.g., discrimination in housing, hospitals/blood sellers liable for emotional harm). Given the potential relativity of such concepts as "status quo" and "change oriented," we sought consensus in the categorization of these claims by using the following operational definitions. Claims were coded restrictive if their central focus concerned the maintenance of established practices and distributional patterns, the regulation of (potentially) infected populations, or the imposition of other social control measures by state institutions. Alternatively, claims were coded expansionary if they focused on redistribution of resources and/or a break from established decisionmaking patterns, on self-regulation at a time when there is no institutional control or self-control as an alternative to institutional control, or on liberty, i.e., seeking to be free from state control when a state institution has acted and the party's challenge to that control is based on some notion of individual rights. 
in divorce proceedings, were the excluded categories for these two variables. ${ }^{9}$

We also measured the relevant cultural attributes of these cases with dummy variables, coded 1 if a particular attribute was present in the language of a judicial opinion and 0 if it was absent. We used the metaphor scheme developed by Ross (1988) to identify the presence of general AIDS-related images that have negative inferences. ${ }^{10}$ Finally, to measure the use of rights discourse, we recorded when a court justifies a ruling by explicitly referring to a federal or state constitutional provision or any legal right created by legislative enactment. We present the codings and descriptive statistics for all variables, including controls for stage of case disposition and geographical location of the court, ${ }^{11}$ in Table 1 . These results are for the entire congregation of 181 reported cases.

Table 1. Codings and Descriptive Statistics for Dependent and Independent Variables $(N=181)$

\begin{tabular}{llll}
\hline & & & $\begin{array}{c}\text { Standard } \\
\text { Deviation }\end{array}$ \\
\hline $\begin{array}{llll}\text { Dependent variable: } \\
\text { Plaintiff wins case }\end{array}$ & Yes $=1$ & 0.43 & 0.50 \\
Social factors: & & & \\
$\quad$ Plaintiff has relative social advantage & Yes $=1$ & 0.21 & 0.41 \\
Plaintiff's claim expansionary/defendant's claim restrictive & Yes $=1$ & 0.67 & 0.47 \\
Defendant's claim expansionary/plaintiff's claim restrictive & Yes $=1$ & 0.22 & 0.42 \\
Cultural variables: & & & \\
$\quad$ Court uses negative AIDS metaphors & Yes $=1$ & 0.36 & 0.48 \\
Court cites legal rights to justify decision & Yes $=1$ & 0.24 & 0.43 \\
Control variables: & & & \\
$\quad$ Case decided at trial or pretrial (vs. appellate) & Yes $=1$ & 0.59 & 0.49 \\
Cases decided by court in California or New York & Yes $=1$ & 0.27 & 0.44 \\
\hline
\end{tabular}

9 We effect-coded the set of dummy variables measuring types of claims so that the coefficients for the two included dummy variables measure differences from the grand mean of $Y$ rather than the mean of the excluded categories (Cohen \& Cohen 1983:198-204).

10 For example, death (e.g., AIDS personifies death, AIDS is looking for victims, AIDS is inevitably a killer); punishment (e.g., a violation of God's law, retribution for wrongdoing); crime (e.g., victim of . .., AIDS is a serial killer, terrorizing victims); war (invaders, enemy, body count, time bomb); otherness (threatens health of the general public, inner-city problem, problem of risk groups, what we must do about them).

11 We considered different ways of measuring the geographical location of the court in order to control for regional variations in the ways courts decide AIDS-related cases. However, we chose to distinguish courts in California and New York from courts in the rest of the country for theoretical reasons. Because these two states contain large and politically active gay populations, we expect that courts in California and New York will see more strategic litigation and plaintiffs with more resource support. 


\section{Analyses and Results}

\section{Regression Analysis of the Entire Case Congregation}

We begin our analysis by estimating a logistic regression equation for the complete congregation of reported AIDS-related cases $(N=181)$. We used logistic regression because our dependent variable, case outcome, is dichotomous. Thus, this model estimates the effects of our social and cultural measures on the unobserved probability that a plaintiff wins a case. We present these results in Table $2 .{ }^{12}$ In addition to the regression coefficients and their standard errors, we include in Table 2 a column of first difference statistics based on the regression coefficients. Each of these scores indicates how much the estimated probability of a plaintiff win changes for a one-unit change (from 0 to 1 ) in the independent variable, holding all other variables constant at their means (King 1989:107-8). We include first dif-

Table 2. Logistic Regression Coefficients, Standard Errors, ${ }^{a}$ and First Differences for the Predictors of the Probabilty of a Plaintiff Winning an AIDS-Related Case, 1983-1989 $(N=181)$

\begin{tabular}{lcc}
\hline & $\begin{array}{c}\text { Logit } \\
\text { Coefficient }\end{array}$ & $\begin{array}{c}\text { First } \\
\text { Difference }\end{array}$ \\
\hline Social factors: & $1.706^{* *}$ & 0.40 \\
Plaintiff has relative social advantage & $(0.618)$ & \\
& 0.216 & 0.05 \\
Plaintiff's claim expansionary/defendant's claim restrictive & $(0.367)$ & \\
& $0.734^{*}$ & 0.18 \\
Defendant's claim expansionary/plaintiff's claim restrictive & $(0.379)$ & \\
& & \\
Cultural factors: & $-0.769^{*}$ & -0.18 \\
Court uses negative AIDS metaphors & $(0.388)$ & \\
Court cites legal rights to justify decision & $1.741^{* *}$ & 0.41 \\
& $(0.419)$ & \\
Control variables: & -0.291 & -0.07 \\
Case decided at trial or pretrial & $(0.362)$ & $0.879^{*}$ \\
Case decided by court in California or New York & 0.399 & 0.22 \\
Constant & $-1.106^{* *}$ & \\
& $(0.432)$ & \\
\% correctly predicted & 76.2 & \\
\hline
\end{tabular}

${ }^{a}$ Standard errors are reported in parentheses.

${ }^{*} p<.05$ (one-tailed test) ${ }^{* *} p<.01$ (one-tailed test)

12 We also estimated models including controls for type of case (criminal vs. civil) and type of court (federal vs. state). Neither of these controls had significant effects in any of the models estimated (full and recursive), nor did their inclusion change the coefficients for any of the other variables in the models. Therefore, for the sake of parsimony, we did not include them in the models reported in Tables $\mathbf{2}$ and 3. 
ferences because they are more intuitive to interpret and compare than logistic coefficients. ${ }^{13}$

Looking at the results in Table 2, we find that two social factors and two cultural factors are significantly related to the probability of a plaintiff win. As expected, relative social advantage has a strong impact on case outcome; if a plaintiff holds a power advantage over the defendant, the probability that the plaintiff will win increases by .40. For example, in one of the first AIDS-related cases, City of New York v. New St. Mark's Baths (1986), the city obtained an injunction closing a local bathhouse as a public nuisance. Similarly, in United States $v$. Moore (1987), the federal government was allowed to bring charges of assault with a deadly weapon against a defendant living with AIDS who had bitten a federal correctional officer. The overall success rate for plaintiffs with a social advantage was $74 \%$ compared with $35 \%$ for less powerful plaintiffs.

As expected, we also find that courts will tend to support parties who seek to maintain existing patterns of regulation and distribution. Courts are more supportive of plaintiffs when they assert restrictive claims that are countered by expansionary claims of defendants. The presence of this combination of claims-making activity in a case significantly increases the probability of a plaintiff win by .18. For example, in In re Peacock (1986), a bank was able to prevent a debtor defendant, who was diagnosed with AIDS, from discharging a loan in bankruptcy court. Similarly, in Two Associates $v$. Brown (1987), a landlord realty company was able to evict the gay life-partner of a tenant who had died of AIDS. Interestingly, however, we find that courts do not "punish" plaintiffs for bringing expansionary claims countered by restrictive defendant claims. As Table 2 indicates, the coefficient for this combination of claims is not statistically significant.

Again as anticipated, the cultural messages embodied in the use of AIDS-related metaphors are significantly associated with case outcome. While AIDS-related metaphors are present in only $36 \%$ of the cases, the presence of such negative AIDS images in the text of an opinion decreases the probability of a plaintiff win by .18. For example, in Doe v. Coughlin (1986), the court denied the request of a prisoner with AIDS for conjugal visits. Images of AIDS as death, plague, and a "thief in the night" communicated the courts' underlying anxiety about AIDS. As such images of

13 We used the following formula, presented by King (1989:107), to compute first differences for our models:

First Difference logit $=\left[1+\exp \left(-X_{j}{ }^{(b)} \beta_{j}-X_{*} \beta_{*}\right)\right]^{-1}-\left[1+\exp \left(-X_{j}^{(a)} \beta_{j}-X_{*} \beta_{*}\right]^{-1}\right.$,

where $X_{j}^{(a)}$ and $X_{j}^{(b)}$ are the values of $X_{j}$ for which the first difference statistic is to be computed (i.e., the difference from $X_{j}^{(a)}$ to $\left.X_{j}^{(b)}\right), \beta_{j}$ is the logistic regression coefficient for $X_{j}$, and $\beta_{*}$ is the vector of coefficients and $X_{*}$ is the vector of means for the remaining variables in the model. Because all our measures are dichotomies, the first difference statistics reported in the tables represent the change in the estimated probability of a plaintiff win associated with a change from 0 to 1 in a particular independent variable. 
AIDS are primarily focused on individuals rather than institutions (e.g., blood banks, hospitals), the detrimental effect of negative AIDS metaphors for plaintiffs is consistent with the relatively high number of individual plaintiffs $(68 \%)$ and the low number of individual defendants $(21 \%)$.

Also as expected, judges were more likely to use rights to justify wins for plaintiffs. The probability of a plaintiff winning is higher (.41) in those cases in which judges use rights discourse to support their decisions. Initially, judges extended protections of the Rehabilitation Act of 1973 to include people living with communicable diseases (see School Board of Nassau County v. Arline 1987), and soon thereafter, judges explicitly conferred these rights' protections on PWAs (see Chalk v. U.S. District Court 1988).

Finally, we note that only one of our control variables had a significant effect on case outcome. Overall, plaintiffs fared better with courts in California and New York; the probability that a plaintiff won increased by .22 if the case was decided by a court in one of these two states. However, whether a case was decided by a trial court or appellate court did not significantly affect the chance of a plaintiff winning the case. ${ }^{14}$

\section{Regression Analysis of Temporal Changes}

The regression results reported in Table 2 are based on the entire set of AIDS-related cases decided between 1983 and 1989. Because time is not incorporated into the model, it is implicitly assumed that relationships between the independent and dependent variables remained constant over the years in which cases reached the court system; that is, on average, the coefficients should summarize relationships for cases decided in 1984 as well as for cases decided in 1989. However, according to Galanter (1990), this assumption may be untenable since the characteristics of case congregations can evolve and change over time. This would seem especially true for AIDS-related cases given the changes in public information and attitudes toward AIDS that occurred during this period. Therefore, to determine whether the effects of our social and cultural variables change, we esti-

14 Our sample contains both trial and appellate court decisions. Therefore, we included a variable in all our models controlling for level of court. This allows us to estimate the relationship between case outcome and each social and cultural variable independent of, or holding constant, the stage of final disposition. While this approach eliminates level of court as an alternative explanation for our findings (i.e., our findings are not an artifact of differences in the probability of a plaintiff winning in trial vs. appellate courts), it does not allow us to determine whether the social, cultural, and temporal dynamics of this case congregation are the same or different for trial and appellate courts. Unfortunately, we do not have enough cases to perform separate analyses by level of court. However, Galanter (1990) does not list level, type (federal vs. state), or geographical location of court as a defining feature of a case congregation and, in fact, tends to combine cases from different kinds of courts in his own examples. Still, it would be interesting to observe whether the dynamics of case congregations vary by features of courts, and we suggest this as an interesting topic for future research. 
mated a series of recursive logistic regression models, looking for changes in the model coefficients (see Brown, Durbin, \& Evans 1975; Isaac \& Griffin 1989; Griffin \& Isaac 1992). Although this approach has generally been used in the study of macro-level historical processes, we believe that it can provide useful insights about the dynamics of any temporally organized sequence of events.

Recursive regression is used to identify temporal contingency in regression models-that is, periods in a time series when regression coefficients change in magnitude and/or sign. This is accomplished by systematically varying the period of time over which a regression model is estimated and then comparing the coefficients from the different estimates. Griffin and Isaac (1992: 168-69) identify three basic strategies for selecting periods for analysis: a forward-moving approach, a backward-moving approach, and a diagonal approach. We used the forward- and backward-moving strategies to assess the stability of the coefficients for the model reported in Table 2.

With the forward-moving approach, the starting point is fixed while the ending point varies; for example, the first model is estimated using observations 1 to $t$, the second using observations 1 to $t+1$, the third using observations 1 to $t+2$. In contrast, the backward-moving approach fixes the end point, allowing the starting point of successive periods to vary; for example, the first model is estimated using observations $t$ to $N$, the second using observations $t-1$ to $N$, the third using observations $t-2$ to $N .^{15}$ Together, these two approaches allow us to observe if the social and cultural dynamics of more recent cases entering the AIDS congregation are different from those already present and whether they produce shifts in the parameter structure of the emerging case congregation. ${ }^{16}$ Figures $1-5$ show the results of the forward and backward recursive logistic regressions for the five significant variables reported in Table $2 .{ }^{17}$

15 It should be noted that the starting and ending points for a recursive regression do not have to be the first and last observations. In fact, as Griffin and Isaac (1992) argue, the selection should be based on theoretical grounds rather than data availability. We used the first and last cases as the starting and ending points in our models because of our interest in the dynamics of a new and still developing case congregation.

16 The diagonal approach fixes the length of the time frame for each estimate and then "slides" this interval over the entire period under investigation, varying both starting and ending points for each successive model estimation. For example, using a fixed time frame of 30 , the first model would be estimated using observations 1 to 30 , the second using observations 2 to 31 , the third using observations 3 to 32, etc. Following the suggestions of Griffin and Isaac (1992:169-70), we used the diagonal approach as a methodological tool to help rule out the possibility that any observed instability in parameter estimates was simply an artifact of the small sample sizes typically found in the initial intervals of the forward and backward approaches.

17 We performed a recursive regression analysis on all the variables in our model. We found that the nonsignificant effects were consistently nonsignificant across all intervals. 
The forward-moving recursive regressions (the A panel in each figure) begin with all cases decided before February 1987 and then add cases moving forward one month at a time until all cases are included. For each successive interval, the complete model from Table 2 is estimated and the coefficients recorded. The resulting series of coefficients for each variable is plotted in the upper portion of the figure using a solid line. The backwardmoving recursive regressions (the $\mathrm{B}$ panel) begin with all cases decided after December 1988 and then add cases moving backward one month at a time until all cases are included. Once
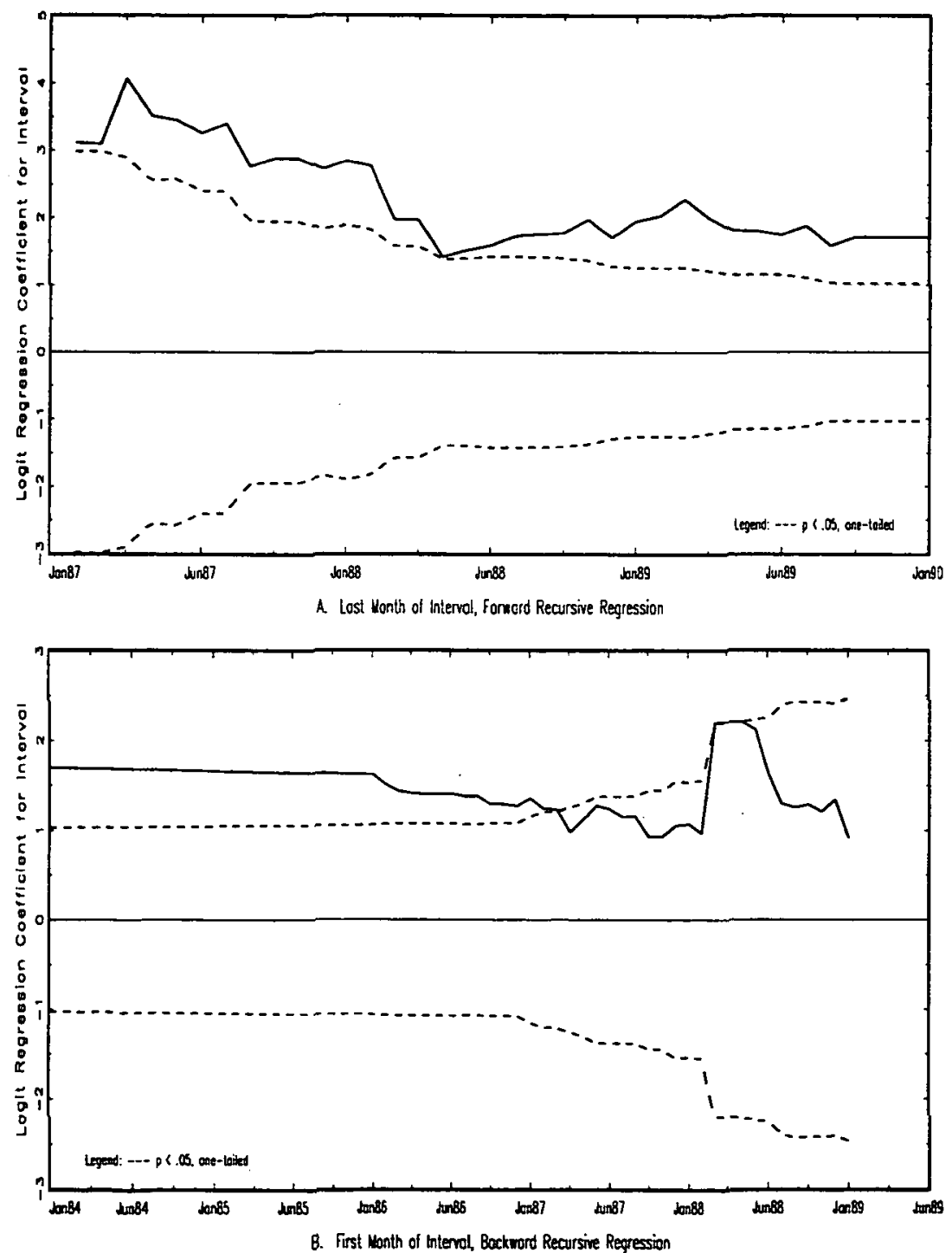

Fig. 1. Forward and backward recursive logistic regressions for the effect of a plaintiff's social advantage on the probability of winning for plaintiffs. 
again, for each successive interval, the model from Table 2 is estimated and the coefficients recorded. These coefficients are plotted in the lower portion of each figure using a solid line. For both approaches, the dates of the initial intervals were based on the number of cases required to provide enough variation in the indicators to make model estimation possible. All graphs also include dotted lines indicating the level of a $5 \%$ test of statistical significance ( $t$-test, one-tailed) across the periods of estimation. Thus, if a coefficient (indicated by the solid line) falls above
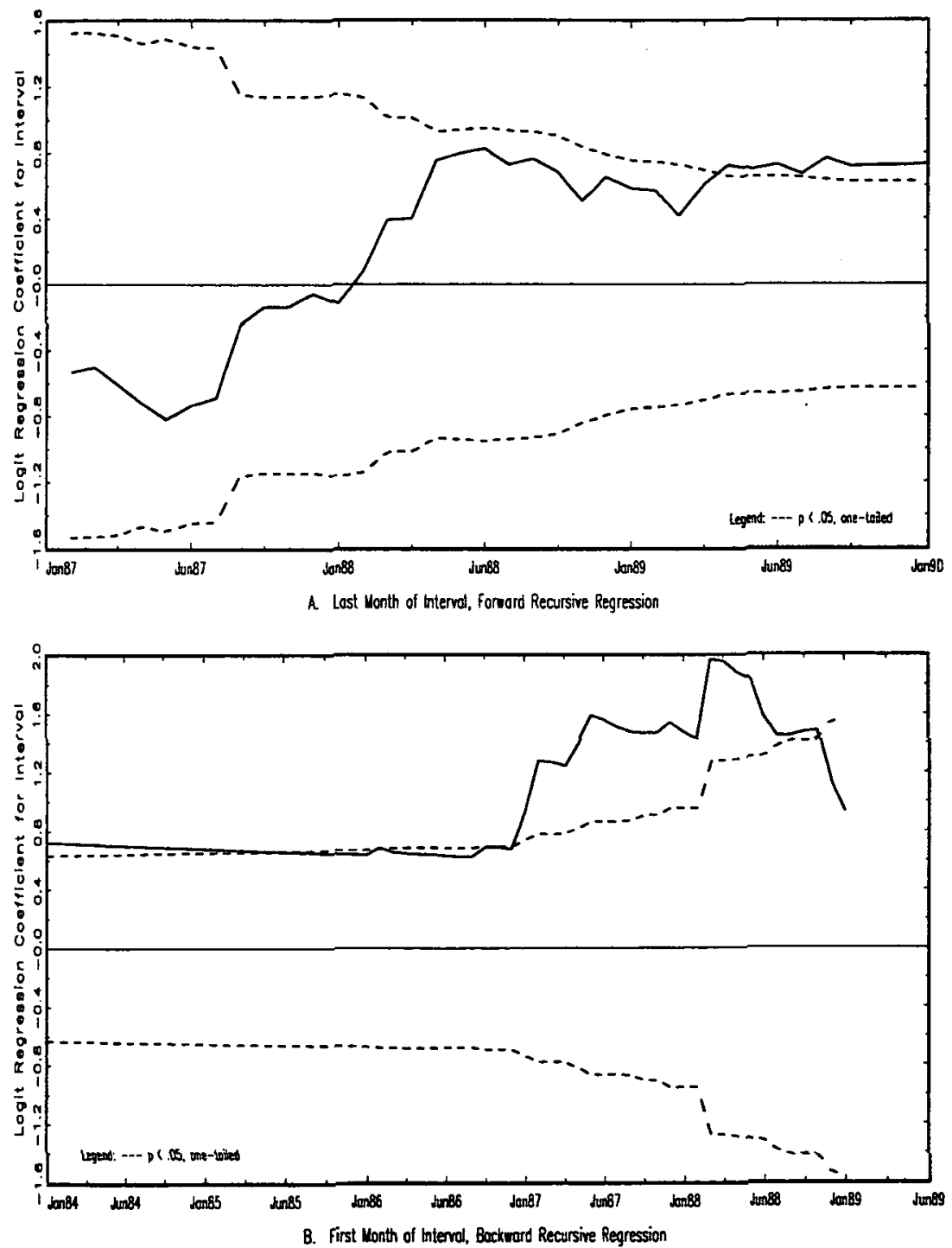

Fig. 2. Forward and background recursive logistic regressions for the effect of a plaintiff's restrictive claim on the probability of winning for plaintiffs. 
(positive) or below (negative) the dotted line, it is statistically significant. Coefficients located between the dotted lines are not statistically significant.

Figures 1,2, 3, and 5 suggest that the effects of four variables changed significantly as the congregation of AIDS-related cases matured. According to Figure 1, the effect of plaintiff's social advantage appears to have declined over time; it had a significant impact on case outcomes for the early cases but not for the later cases (observe the backward recursive regression results in panel
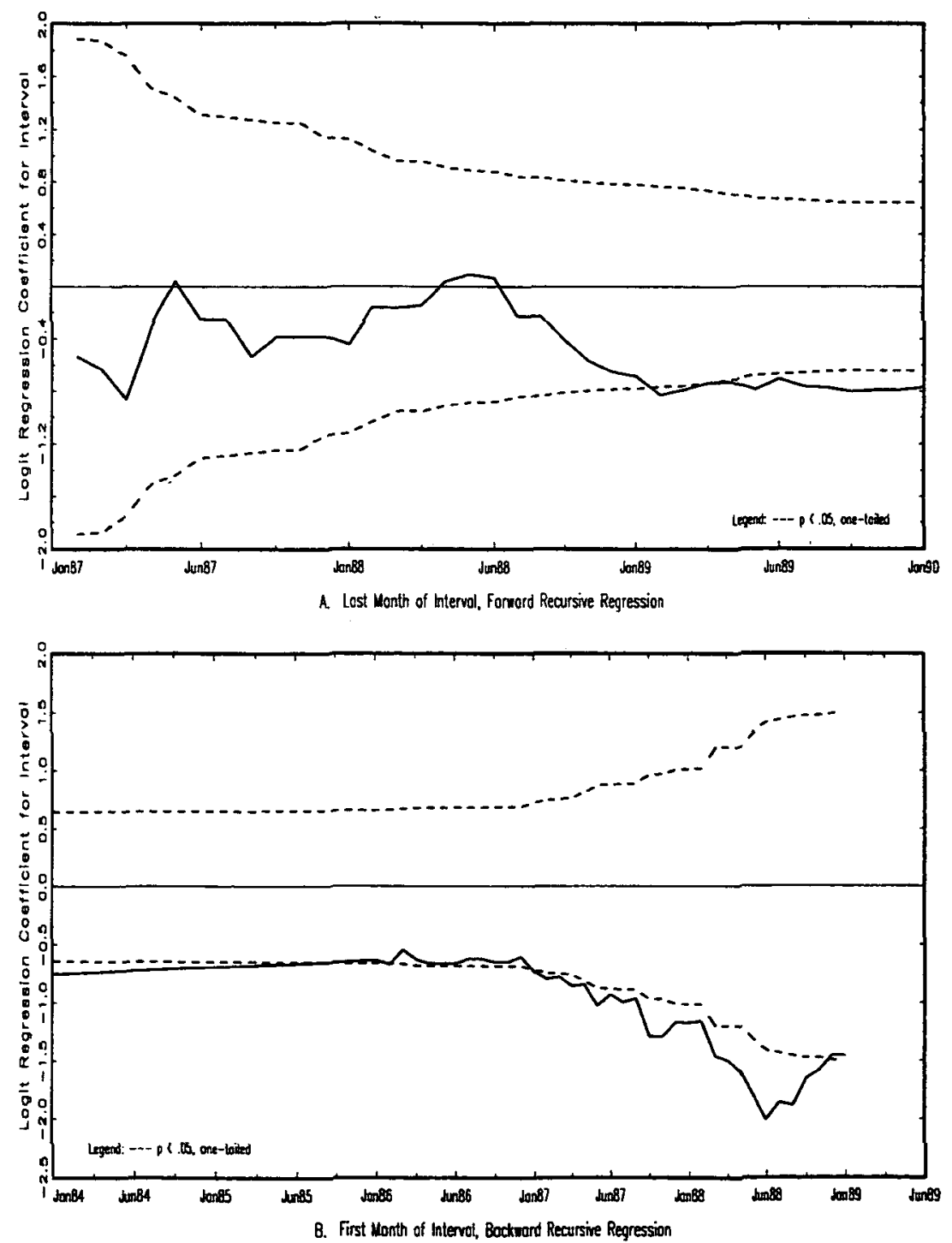

Fig. 3. Forward and background recursive logistic regressions for the effect of the court's use of negative AIDS metaphors on the probability of winning for plaintiffs. 
B of Fig. 1). In contrast, Figures 2, 3, and 5 indicate that the effects of plaintiff's restrictive claim, court's use of negative AIDS metaphors, and geographical location of the court grew as the congregation matured, becoming statistically significant only as the later cases entered the congregation. Finally, the recursive regression results displayed in Figure 4 suggest that only one variable had a relatively stable significant effect for the entire life of the congregation captured in our data: the court's use of individual legal rights to justify decisions.
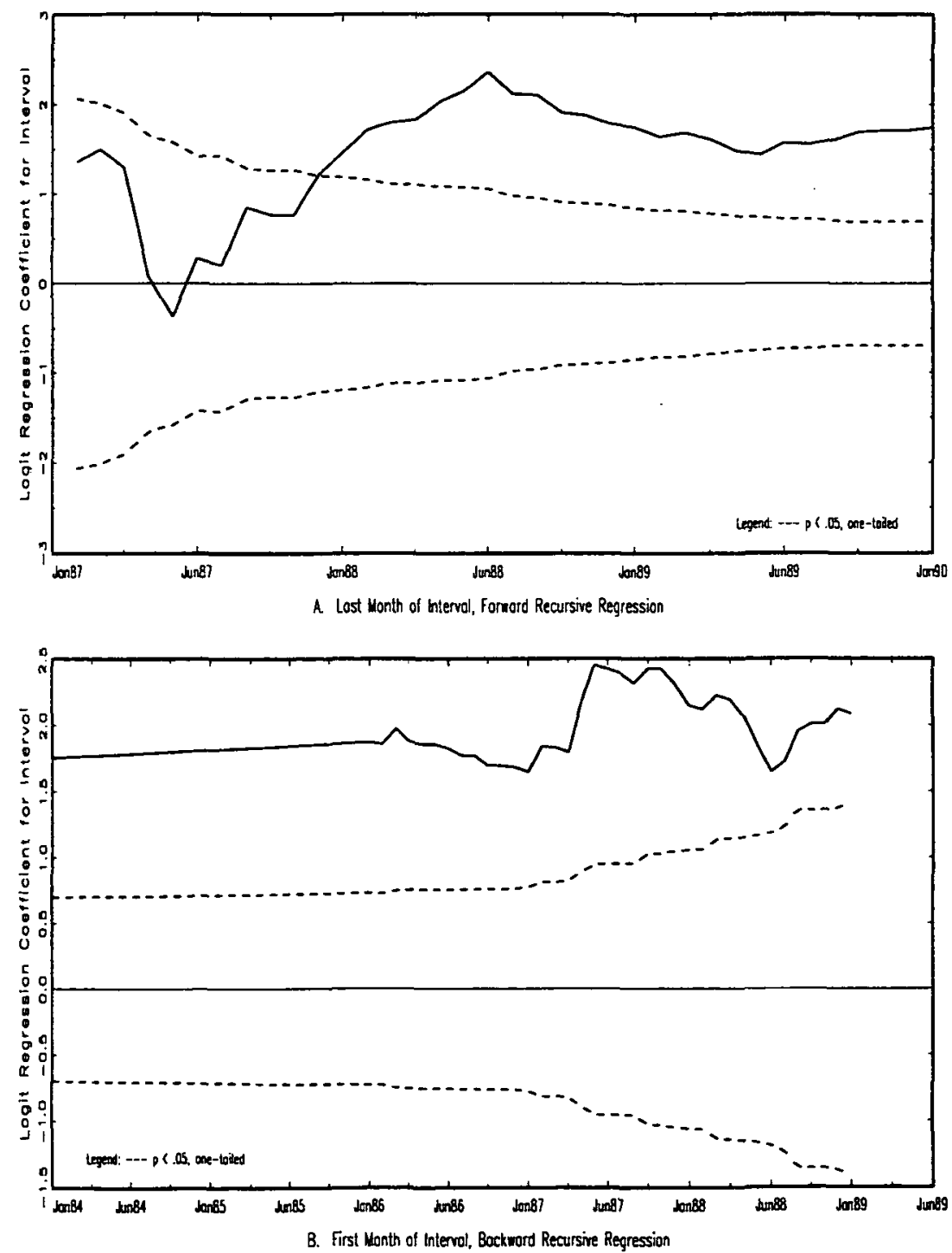

Fig. 4. Forward and background recursive logistic regressions for the effect of the court's use of individual rights on the probability of winning for plaintiffs. 
On the basis of these recursive regression results, we divided our case congregation into two subsamples: cases decided through December 1987 and cases decided after that date. We then estimated a separate logistic regression model for each of these subsamples. We report these results in Table 3. They confirm the general patterns of parameter change displayed in Figures 1, 2, 3, and 5 and parameter constancy displayed in Figure 4 .
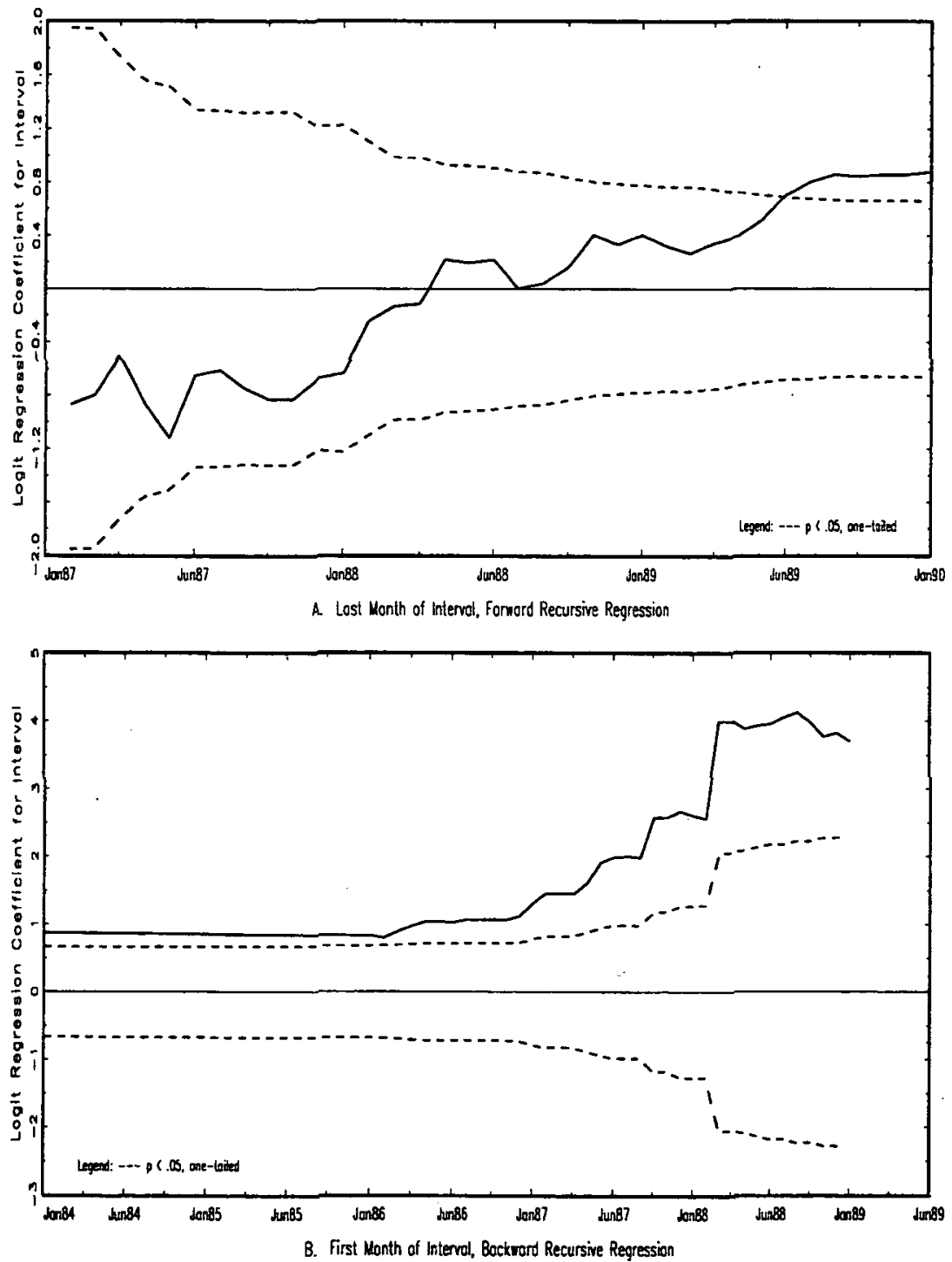

Fig. 5. Forward and background recursive logistic regressions for the effect of the court's location in California or New York on the probability of winning for plaintiffs. 
Table 3. Logistic Regression Coefficients, Standard Errors, ${ }^{a}$ and First Differences for the Predictors of the Probabilty of a Plaintiff Winning an AIDS-Related Case for Two Time Periods, 1/83-12/87 and $1 / 88-12 / 89(N=181)$

\begin{tabular}{|c|c|c|c|c|}
\hline & \multicolumn{2}{|c|}{$1 / 83-12 / 87(N=73)$} & \multicolumn{2}{|c|}{$1 / 88-12 / 89(N=108)$} \\
\hline & $\begin{array}{c}\text { Logit } \\
\text { Coefficient }\end{array}$ & $\begin{array}{c}\text { First } \\
\text { Difference }\end{array}$ & $\begin{array}{c}\text { Logit } \\
\text { Coefficient }\end{array}$ & $\begin{array}{c}\text { First } \\
\text { Difference }\end{array}$ \\
\hline \multicolumn{5}{|l|}{ Social factors: } \\
\hline Plaintiff has relative social advantage & $\begin{array}{l}2.843^{* *} \\
(1.131)\end{array}$ & 0.60 & $\begin{array}{c}1.072 \\
(0.921)\end{array}$ & 0.24 \\
\hline $\begin{array}{l}\text { Plaintiff's claim expansionary/ } \\
\text { defendant's claim restrictive }\end{array}$ & $\begin{array}{c}0.246 \\
(0.652)\end{array}$ & 0.05 & $\begin{array}{c}0.038 \\
(0.522)\end{array}$ & 0.01 \\
\hline $\begin{array}{l}\text { Defendant's claim expansionary/ } \\
\text { plaintiff's claim restrictive }\end{array}$ & $\begin{array}{l}-0.112 \\
(0.694)\end{array}$ & -0.02 & $\begin{array}{l}1.478^{* *} \\
(0.570)\end{array}$ & 0.31 \\
\hline \multicolumn{5}{|l|}{ Cultural factors: } \\
\hline Court uses negative AIDS metaphors & $\begin{array}{l}-0.446 \\
(0.670)\end{array}$ & -0.08 & $\begin{array}{l}-1.172^{*} \\
(0.606\end{array}$ & -0.28 \\
\hline $\begin{array}{l}\text { Court cites legal rights to justify } \\
\text { decision }\end{array}$ & $\begin{array}{r}1.466^{*} \\
(0.712)\end{array}$ & 0.32 & $\begin{array}{l}2.152 * * \\
(0.633)\end{array}$ & 0.44 \\
\hline \multicolumn{5}{|l|}{ Control variables: } \\
\hline Case decided at trial or pretrial & $\begin{array}{l}-0.693 \\
(0.666)\end{array}$ & -0.14 & $\begin{array}{c}0.103 \\
(0.540)\end{array}$ & 0.03 \\
\hline $\begin{array}{l}\text { Case decided by court in California or } \\
\text { New York }\end{array}$ & $\begin{array}{l}-0.635 \\
(0.733)\end{array}$ & -0.11 & $\begin{array}{l}2.606^{* *} \\
(0.760)\end{array}$ & 0.51 \\
\hline Constant & $\begin{array}{r}-1.385^{*} \\
(0.808)\end{array}$ & & $\begin{array}{c}-1.001^{*} \\
(0.590)\end{array}$ & \\
\hline$\%$ correctly predicted & 76.7 & & 80.6 & \\
\hline
\end{tabular}

${ }^{a}$ Standard errors are reported in parentheses.

${ }^{*} p<.05$ (one-tailed test) $\quad * * p<.01$ (one-tailed test)

As we expected, the effect of relative social advantage on case outcome declined over time. According to Table 3, plaintiff's relative social advantage was significantly related to plaintiff wins in the formative years of this case congregation but not in the later years. This change may reflect the historical pattern of judicial behavior in coping with epidemics. Historically, the initial fear and confusion engendered by disease scares led to marked deference by the courts toward authoritative institutions, especially public health and criminal justice institutions, who were given discretionary power to control disease (Brandt 1987). Reductions in the level of fear and confusion about AIDS, sparked by medical and advocacy groups, may have increased judicial propensities to grant the demands of the less socially powerful, although we continue to see deference to criminal justice institutions.

Court decisions involving AIDS in school settings dramatically exemplify this process of public health involvement to the benefit of the less socially powerful. In the early years of the AIDS crisis in the United States, local school boards often restricted normal school access for children living with AIDS. The first such cases, District 27 Community School v. Board of Education (1986) and Board of Education v. Cooperman (1986), rather than involving in- 
dividuals, involved contestation between state level health and education officials and local school boards over the issue of admitting children living with AIDS into school classrooms. From the beginning, the courts deferred to powerful social institutions, to legislative policymaking, especially the Rehabilitation Act of 1973, public health authorities, and to "the rationality behind ... medical and scientific evidence" (District 27 Community School, p. 329 ). With such obvious deference, and with the support of the medical establishment, individuals began more and more to contest local school boards over their refusal to provide adequate, least restrictive alternatives to children living with AIDS who were now considered handicapped. As petitioning individuals increasingly won their cases (e.g., Thomas v. Atascadero Unified School District 1987; Ray v. School District 1987), there was less need to contest such issues in court. By 1989, the courts had returned to upholding traditional school authority or arbitrating minor issues. The four cases in 1989 either backed the implementation of school AIDS policies (Child by Parent v. Spillane 1989), backed teaching about AIDS in schools (Ware v. Valley Stream High School District 1989), settled minor issues concerning attorney fees (Child v. Spillane 1989), or settled the meaning of "least restrictive" alternatives between courts (Martinez $v$. School Board 1989).

Table 3 shows that the significant effects of plaintiff's restrictive claims and of the use of negative AIDS metaphors are relatively recent features of this case congregation. According to Table 3 , neither of these variables exerts a significant effect on the probability of a plaintiff win in the early cases, but both became significant in the second time period. The change in the importance of plaintiffs' restrictive claims may be explained, at least in part, by the changes in the composition of cases in the evolving AIDS congregation. By 1989 , almost all restrictive claims by plaintiffs involved cases where the state was criminally prosecuting defendants. For example, in Cooper v. State (1989), the court rationalized that defendant's gay lifestyle potentially exposed the victim of his sexual battery to AIDS, creating therefore a valid aggravating circumstance to exceed sentencing guidelines. Similarly, in People v. Alderson (1989), trespass convictions against members of ACT-UP, an AIDS advocacy group, were validated after ACT-UP had staged a sit-in protest against anticipated decreases in funding for AIDS. Thus, the general tendency of courts to defer to state criminal control of disease scares creates the overall significant relationship between plaintiff's restrictive claim and case outcome. This is consistent with other studies which find that in the arena of AIDS, courts have continued their historical tradition of deferring to criminal justice control agencies (Gregware 1994).

We thought that the relationship between the use of negative AIDS metaphors and case outcome might decline over time. As 
Table 3 indicates, the opposite occurred. This change in the importance of AIDS metaphor use relative to plaintiff success may be related to party characteristics. In both time periods, medical businesses such as hospitals and blood banks were never plaintiffs; they only defended against claims by individuals. However, in the later cases we find a much greater tendency by courts to use negative AIDs metaphors in cases involving medical businesses (invariably won by the medical businesses). Thus, the threat to the medical establishment, especially in claims seen as threats to the blood supply which it managed, increasingly invoked negative and fearful portrayals of AIDS. For example, in Miles Laboratories v. Doe (1989), AIDS was characterized as "life threatening" or "inevitably fatal," while in Cutler v. Graduate Hospital (1989), the court talked about the "onslaught of the AIDS virus" as a "threat to patients receiving blood."

Our recursive regression analysis also provides some interesting insights on how courts use legal rights in AIDS-related litigation. Critical legal theorists have argued that legal doctrines and rights do not determine case outcomes but rather legitimize sets of prevailing judicial values and assumptions. Certainly the relationships between social status, restrictive claims, and negative AIDS metaphor use, which are significant when rights use is controlled for, support the proposition that prevailing values and assumptions are important to case outcomes. However, the use of rights is also significantly related to case outcome when social status, type of claims, and negative metaphor use are controlled for. Thus, judicial use of the language of rights was important regardless of whether plaintiffs were seeking through their claims to maintain the status quo or change the distribution of social benefits. Further, rights do not even serve directly to legitimize other significant factors such as social power, nature of claim, or fear related to AIDS. There was little if any relationship between the use of rights and these other variables. ${ }^{18}$ Instead, we suggest that rights provide the judiciary with a language and rationale for granting the claims of plaintiffs, who are primarily individuals. The consistent positive relationship between rights use and wins for plaintiffs may be an institutional "artifact" of the means available to courts to support and recognize the claims of plaintiffs.

\section{Conclusion}

Our temporal analysis of the opinions of AIDS-related cases suggests the emergence of more than one AIDS case congregation by the end of the 1980s, at least among reported cases. The initial construction of AIDS as a gay disease (re)mobilized gay

18 The relevant correlations are: -.10 (court's use of rights with plaintiff's social advantage), .14 (court's use of rights with plaintiff's expansionary claim), and -.17 (court's use of rights with court's use of negative AIDS metaphors). 
activists (Cruikshank 1992:180-89), including gay rights litigators who saw up close the problems that white, gay people with AIDS (PWAs) faced in the workplace, housing, and health care, and the activists responded by forming alliances with other organizations, such as medical and public health organizations, to press antidiscrimination claims. The decreasing significance of social advantage, as well as the increasing importance of the geographical location of the court, may both be a reflection of this wellsupported campaign to stretch the social and legal construction of people with disabilities to be inclusive of PWAs (Aiken \& Musheno 1994).

By 1989, HIV-related discrimination cases had a recognized career in the legal sphere. When gay PWAs and children living with HIV had the resources and stamina to press claims of discrimination in housing, the workplace, and public accommodations, they would have a reasonable probability of prevailing as people with disabilities, even when facing more powerful entities (e.g., local school boards, employers). Moreover, in jurisdictions with strong gay communities, governmental agencies, including human rights commissions and state boards of education, showed an increasing willingness to press cases on behalf of PWAs experiencing discrimination.

However, the increasing tendency of the courts to affirm restrictive claims and to draw on stigmatizing metaphors suggests a second case congregation related to the criminalization of AIDS. The second half of the 1980s represents a period in which attention shifted to heterosexual transmission of AIDS and the threat HIV posed to the "general public" (Cook \& Colby 1992; Musheno 1994). The National Institute of Drug Abuse funded projects to use survey and ethnographic research to study specific populations suspected of being vectors to the mainstream public, particularly intravenous drug users and sex workers (Glick-Schiller 1992; Musheno 1995).

Arrests of sex workers increased and PWAs, including HIVpositive inmates, experienced felony arrests for such acts as biting and spitting (Dalton 1993; Gregware 1994). The judiciary contributed to the construction of AIDS criminalization by deferring to the agencies of the justice system and by communicating the popular view that marginalized groups, among them prisoners and street sex works, were vectors of transmissibility to the "mainstream" population (Aiken \& Musheno 1994). They did this in spite of medical and public health testimony that countered these popular notions about the transmission of AIDS.

As heterosexual transmission and the related fears about infection of the mainstream population emerged as a central policy and media concern in the late 1980 s, the judiciary affirmed the restrictive claims-making activities of criminal justice agencies and rationalized its actions by invoking the language of fear and 
stigmatization of PWAs. The criminalization of AIDS cases sent a message that the courts intended to be vigilant in controlling the spread of the epidemic to the mainstream of America, consistent with the historical response of the courts to enable repression of already stigmatized populations as an effective symbolic response to lethal epidemics. ${ }^{19}$

In addition to uncovering two distinct case congregations related to AIDS, we suggest how the judiciary (re)secures its own legitimacy by selectively privileging cultural and social dynamics at work in the AIDS semi-autonomous social field (generally see Moore 1978). As a constitutive force in the gay liberation movement, rights talk emerged immediately as a vehicle for rallying support for claims-making activities related to AIDS in gay communities throughout the United States (Brigham 1994). Gay rights litigators used rights expressions to accumulate third-party support for claims and undertook strategic litigation to that end (see Aiken \& Musheno 1994). In addition, as our analysis indicates, courts used rights to justify many appellate cases where gays and children were plaintiffs, reinforcing the powerful notion that rights serve the side of justice. This benevolent message-one consistent with liberal ideology about the courts and rights-appeared early in the congregation and was continuously communicated throughout the $1980 \mathrm{~s}$.

Returning to the sociolegal construct "case congregation," we encourage further inquiry using methods that are sensitive to temporal contingency in the importation of social and cultural messages and exploration of how these messages are selectively woven together as the judiciary constructs what Galanter (1990) describes as the "features" and "history" of congregations. Moreover, we urge scholars to look through the institution of the courts to see how the ordering of congregations (re)constitutes judicial legitimacy while selectively privileging institutions and

19 We believe that the second case congregation uncovered in our analysis represents the judicial response to the (re)characterization of AIDS as an epidemic threatening the mainstream, heterosexual population. The temporal sequencing of the shift in the sociocultural dynamics of these cases corresponds with governmental, medical, and massmediated pronouncements about the threat of AIDS to the "mainstream" public, taking into account the lag time associated with the litigation process. Moreover, the language of the judicial rulings mirrors the discourse evident in the larger culture after 1985 (see Rushing 1995:148-54). Of course, other explanations are possible. For example, it could be argued that the increase in AIDS-related criminal cases corresponding with this time period reflects a broader trend of litigation in the criminal law arena related to the war on drugs. However, the cases specific to the congregation are, for the most part, unrelated to drug offenses or drug trafficking. Also, it is possible that the dramatic increase in the judicial referencing of negative AIDS metaphors may reflect a decrease in judicial confidence in medical testimony and scientific data related to AIDS. As we point out in the text, the strong standing of medical science has been shaken by the AIDS epidemic. To test this possible explanation empirically, we also estimated models including a variable measuring whether a court cites medical/scientific evidence to justify its decision. The effect of this variable was never statistically significant over the entire period under study. Further, it did not display any shift corresponding to the emergence of the second case congregation. 
groups operating in the relevant semi-autonomous field (Hunt 1993).

\section{References}

Aiken, Jane Harris, \& Michael Musheno (1994) "Why Have-Nots Win in the HIV Litigation Arena: Socio-Legal Dynamics of Extreme Cases," 16 Law E Policy 267-98.

Albert, E. (1986) "Illness and Deviance: The Response of the Press to AIDS," in D. M. Feldman and T. M. Johnson, eds., The Social Dimensions of AIDS: Method and Theory. New York: Praeger.

Bayer, Ronald (1989) Private Acts, Public Consequences: ADS and the Politics of Public Health. New York: Free Press.

Black, Donald (1976) The Behavior of Law. New York: Academic Press.

(1984) "Social Control as Dependent Variable," in D. Black, ed., Toward a General Theory of Social Control, vol. 1: Fundamentals. Orlando, FL: Academic Press.

- (1989) Sociological Justice. New York: Oxford Univ. Press.

- (1990) "The Elementary Forms of Conflict Management," in School of Justice Studies Editorial Board, eds., New Directions in the Study of Justice, Law and Social Control. New York: Plenum.

Brandt, Allen M. (1987) "An Historical Perspective," in Dalton et al. 1987.

Brigham, John (1994) "Sexual Entitlement: Rights and AIDS, the Early Years," 16 Law $\mathcal{E}$ Policy 249-66.

Brown, R. L., J. Durbin, \& J. M. Evans (1975) "Techniques for Testing the Constancy of Regression Relationships over Time," 37 (ser. B) J. of the Royal Statistical Society 149-92.

Burris, Scott, Harlon L. Dalton, Judith Leonie Miller, \& the Yale AIDS Law Project (1993) AmS Law Today. New Haven, CT: Yale Univ. Press.

Canan, Penelope, Gloria Satterfield, Laurie Larson, \& Martin Kretzmann (1990) "Political Claims, Legal Derailment, and the Context of Disputes," 24 Law E⿱ Society Rev. 923-52.

Cohen, Jacob, \& Patricia Cohen (1983) Applied Multiple Regression/Correlation Analysis for the Behavioral Sciences. 2d ed. Hillsdale, NJ: Lawrence Erlbaum Associates.

Conley, John M., \& William M. O'Barr (1990) Rules versus Relationships: The Ethnography of Legal Discourse. Chicago: Univ. of Chicago Press.

Cook, Timothy E., \& David C. Colby (1992) "The Mass-Mediated Epidemic: The Politics of AIDS on the Nightly Network News," in Fee \& Fox 1992b.

Crimp, Douglas (1988a) "Introduction: AIDS: Cultural Analysis/Cultural Activism," in Crimp 1988b.

Crimp, Douglas, ed. (1988b) AIDS: Cultural Analysis and Cultural Activism. Cambridge: Massachusetts Institute of Technology Press.

Cruikshank, Margaret (1992) The Gay and Lesbian Liberation Movement. New York: Routledge.

Dalton, Harlon L. (1993) "Criminal Law," in Burris et al. 1993.

Dalton, Harlon L., Scott Burris, \& the Yale AIDS Law Project, eds. (1987) ADS and the Law: A Guide for the Public. New Haven, CT: Yale Univ. Press.

Danelski, David J. (1984) "Law from a Political Perspective," 36 Western Political Science Rev. 548-51.

Dowling, Harry Filmore (1977) Fighting Infection: Conquests of the Twentieth Century. Cambridge: Harvard Univ. Press.

Drass, Kriss A., \& J. William Spencer (1987) "Accounting for Pre-sentencing Recommendations: Typologies and Probation Officers' Theory of Office," 34 Social Problems 277-93.

Durey, Michael (1979) The Return of the Plague: British Society and the Cholera 1831-2. New York: Humanities Press. 
Fee, Elizabeth, \& Daniel Fox (1992a) "Introduction: The Contemporary Historiography of AIDS," in Fee \& Fox 1992b.

Fee, Elizabeth, \& Daniel Fox, eds. (1992b) ADS: The Making of a Chronic Disease. Berkeley: Univ. of California Press.

Fischl, Richard Michael (1987) "Some Realism about Critical Legal Studies," 41 Univ. of Miami Law Rev. 505-32.

Gamson, Josh (1989) "Silence, Death, and the Invisible Enemy: AIDS Activism and Social Movement Newness," 36 Social Problems 351-67.

Galanter, Marc (1974) "Why the 'Haves' Come out Ahead: Speculation on the Limits of Legal Change," 9 Law E Society Rev. 95-160.

_ (1990) "Case Congregations and Their Careers," 24 Law $\mathcal{E}$ Society Rev. 371-95.

Glick-Schiller, Nina (1992) "What's Wrong with the Picture? The Hegemonic Construction of Culture in AIDS Research in the United States," 6 Medical Anthropology Q. 237-54.

Gostin, Larry (1987) "Traditional Public Health Strategies," in Dalton et al. 1987.

Gregware, Peter R. (1994) "Courts, Criminal Process, and AIDS: The Institutionalization of Culture in Legal Decision Making," 16 Law $\mathcal{E}$ Policy 341-62.

Griffin, Larry J., \& Larry W. Isaac (1992) "Recursive Regression and the Historical Use of 'Time' in Time-Series Analysis of Historical Process," 25 Historical Methods 166-79.

Hollibaugh, Amber, Mitchell Karp, \& Katy Taylor (1988) "The Second Epidemic," in Crimp 1988b.

Hunt, Alan (1993) Explorations in Law and Society: Towards a Constitutive Theory of Law. New York: Routledge.

Inciardi, James A. (1992) The War on Drugs II: The Continuing Epic of Heroin, Cocaine, Crack, Crime, AIDS, and Public Policy. Mountain View, CA: Mayfield.

Ingrassia, Lawrence (1993) "Fighting Words: Gay, Lesbian Groups Seek to Expunge Bias They See in Language," Wall Street J., 3 May,. p. 1.

Isaac, Larry W., \& Larry J. Griffin (1989) "Ahistoricism in Time-Series Analyses of Historical Process: Critique, Redirection, and Illustrations from U.S. Labor History," 54 American Sociological Rev. 873-90.

Jarvis, Robert M., Michael L. Closen, Donald H. J. Hermann, \& Arthur S. Leonard (1991) ADS Law in a Nutshell. St. Paul, MN: West Publishing Co.

Jonsen, Albert R., \& Jeff Stryker (1993) The Social Impact of ADS in the United States. Washington: National Academy Press.

Kairys, David (1982) "Introduction," in D. Kairys, ed., The Politics of Law: A Progressive Critique. New York: Pantheon.

Kelman, Mark (1987) A Guide to Critical Legal Studies. Cambridge: Harvard Univ. Press.

King, Gary (1989) Unifying Political Methodology: The Likelihood Theory of Statistical Inference. New York: Cambridge Univ. Press.

Laumann, Edward O., \& David Knoke (1987) The Organizational State: Social Policy in National Policy Domains. Madison: Univ. of Wisconsin Press.

Leonard, Arthur S. (1993) "Discrimination," in Burris et al. 1993.

Levi, Edward H. (1949) An Introduction to Legal Reasoning. Chicago: Univ. of Chicago Press.

Mather, Lynn, \& Barbara Yngvesson (1980-81) "Language, Audience and the Transformation of Disputes," 15 Law E Society Rev. 15:775-821.

McClain, Charles (1988) "Of Medicine, Race and American Law: The Bubonic Plague Outbreak of 1900," 13 Law Ev Social Inquiry 447-514.

Merry, Sally Engle (1990) Getting Justice and Getting Even: Legal Consciousness among Working-Class Americans. Chicago: Univ. of Chicago Press.

Merry, Sally Engle, \& Susan Silbey (1984) "What Do Plaintiffs Want? Reexamining the Concept of Dispute," 9 Justice System J. 151-78. 
Moore, Sally Falk (1978) Law as Process: An Anthropological Approach. London: Routledge.

Morris, R. J. (1976) Cholera 1832: The Social Response to an Epidemic. New York: Holmes \& Meier Publishers.

Musheno, Michael (1994) "Introductory Essay: Socio-legal Dynamics of AIDS," 16 Law E Policy 235-48.

- (1995) "Legal Consciousness on the Margins of Society: Struggles against Stigmatization in the AIDS Crisis," 2 Identities: Global Studies in Culture E Power 101-22.

Musheno, Michael C., Peter R. Gregware, \& Kriss A. Drass (1991) "Court Management of AIDS Disputes: A Sociolegal Analysis," 16 Law $\mathcal{E}$ Social Inquiry 737-74.

Nelkin, Dorothy, \& Sander L. Gilman (1988) "Placing Blame for Devastating Disease," 55 Social Research 361-78.

Odets, Walt (1994) "AIDS Education and Harm Reduction for Gay Men: Psychological Approaches for the 21st Century," 9 ADS E' Social Policy J. 3-15.

Padgug, Robert A., \& Gerald M. Oppenheimer (1992) "Riding the Tiger: AIDS and the Gay Community," in Fee \& Fox 1992b.

Palumbo, Dennis, Michael Musheno, \& Michael Hallett (1994) "The Political Construction of Alternative Dispute Resolution and Alternatives to Incarceration," 17 Evaluation $\mathcal{E}$ Program Planning 197-203.

Rosenberg, Charles E. (1962) The Cholera Years: The United States in 1832, 1849, and 1866. Chicago: Univ. of Chicago Press.

(1988) "The Definition and Control of Disease," 55 Social Research 327-30.

Ross, Judith Wilson (1988) "Ethics and Language of AIDS," in C. Pierce \& D. Van de Veer, eds., ADS, Ethics and Public Policy. Belmont, CA: Wadsworth.

Rowland, C. K., \& Robert A. Carp (1996) Politics and Judgement in Federal District Courts. Lawrence: Univ. of Kansas Press.

Rushing, William A. (1995) The AIDS Epidemic: Social Dimensions of an Infectious Disease. Boulder, CO: Westview Press.

Sarat, Austin (1984) "The Maturation of Political Jurisprudence," 36 Western Political Science Rev. 551-58.

Schneider, Anne, \& Helen Ingram (1993) "Social Construction of Target Populations: Implications for Politics and Policy," 87 American Political Science Rev. 334-47.

Shilts, Randy (1987) And the Band Played on: Politics, People and the AIDS Epidemic. New York: St. Martin's Press.

Siegelman, Peter, \& John J. Donohue III (1990) "Studying the Iceberg from Its Tip: A Comparison of Published and Unpublished Employment Discrimination Cases," 24 Law E' Society Rev. 1133-70.

Singer, Eleanor, Theresa Rogers, \& Mary Corcoran (1987) "The Polls-a Report," 50 Public Opinion Q. 580-95.

Smith, Rogers M. (1988) "Political Jurisprudence, the "New Institutionalism," and the Future of Public Law," 82 American Political Science Rev. 89-108.

Songer, Donald R. (1988) "Nonpublication in the U.S. District Courts: Official Criteria versus Inferences from Appellate Review," $50 \mathrm{~J}$. of Politics 206-19.

Sontag, Susan (1990) Illness as Metaphor and AIDS and Its Metaphors. New York: Doubleday Anchor.

Spector, Malcom, \& John I. Kitsuse (1977) Constructing Social Problems. Menlo Park, CA: Cummings.

Stookey, John A. (1990) "Trials and Tribulations: Crisis, Litigation, and Legal Change," 24 Law E' Society Rev. 497-520.

Sutherland, Ian (1972) "When Was the Great Plague? Mortality in London, 1563-1665," in D. V. Glass \& R. Revelle, eds., Population and Social Change. London: Edward Arnold. 
Trubek, David M., \& John P. Esser (1989) “'Critical Empiricism' in American Legal Studies: Paradox, Program, or Pandora's Box?" 14 Law E' Social Inquiry 3-52.

Tushnet, Mark (1984) "Critical Legal Studies and Constitutional Law: An Essay in Deconstruction," 36 Stanford Law Rev. 623-47.

Unger, Roberto Mangabeira (1986) The Critical Legal Studies Movement. Cambridge: Harvard Univ. Press.

Wallace, Joyce (1989) "Case Presentation of AIDS in the United States," in P. Ma \& D. Armstrong, eds., AIDS and Infections of Homosexual Men. 2d ed. Boston: Butterworth.

Wheeler, Stanton, Bliss Cartwright, Robert A. Kagan, \& Lawrence M. Friedman (1987) 'Do the 'Haves' Come out Ahead? Winning and Losing in State Supreme Courts, 1870-1970," 21 Law EO Society Rev. 403-45.

Yngvesson, Barbara (1988) "Making Law at the Doorway: The Clerk, the Court and the Construction of Community in a New England Town," 22 Law $\mathcal{E}^{\circ}$ Society Rev. 409-48.

\section{Cases}

Board of Education v. Cooperman, 507 A.2d 253 (N.J. Super. A.D. 1986).

Chalk v. U.S. District Court, 840 F.2d 701 (CA9 Cal. 1988).

Child v. Spillane, 866 F.2d 691 (4th Cir. 1989).

Child by Parent v. Spillane, 875 F.2d 314 (E.D. Va. 1989).

City of New York v. New St. Mark's Baths, 497 N.Y.S. 2d 979 (Supp. 1986).

Cooper v. State, 539 So. 2d 508 (Fla. App. 1 Dist. 1989).

Cutler v. Graduate Hospital, 717 F.Supp. 338 (E.D. Pa. 1989).

District 27 Community School Board v. Board of Education, 502 N.Y.S. $2 d 325$ (Supp. 1986).

Doe v. American Red Cross Blood Services, 377 S.E. 2d 323 (S.C. 1989).

Doe v. Coughlin, 505 N.Y.S. 2d 534 (Supp. 1986).

Dunn v. White, 880 F.2d 1188 (10th Cir. 1989).

Hawley v. Evans, 716 F. Supp. 601 (N.D. Ga. 1989).

In re Peacock, 59 B.R. 568 (Bankr. S.D.Fla. 1986).

Martinez v. School Board, 711 F. Supp. 1066 (M.D. Fla. 1989).

McKee v. Miles Laboratories, 675 F. Supp. 1060 (E.D. Ky. 1987).

Miles Laboratories v. Doe, 556 A.2d 1107 (Md. 1989).

People v. Alderson, 540 N.Y.S.2d 948 (N.Y. City Crim. Ct. 1989).

Ray v. School District, 666 F. Supp. 1524 (M.D. Fla. 1987).

Raytheon Co. v. Fair Employment \& Housing Commission, 261 Cal. Rptr. 197 (Cal. App. 2 Dist. 1989).

School Board of Nassau County v. Arline, 107 S.Ct. 1123 (1987).

Shelvin v. Lykos, 741 S.W. 2d 178 (Tex. App.-Houston [1st Dist.] 1987).

Smith v. Emery, 42 N.Y.S. 258 (1896).

Suburban Video v. City of Delafield, 694 F. Supp. 585 (E.D. Wis. 1988).

Thomas v. Atascadero Unified School District, 662 F. Supp. 376 (C.D. Cal. 1987).

Two Associates v. Brown, 513 N.Y.S.2d 966 (A.D. 1 Dept. 1987).

United States v. Moore, 669 F. Supp. 289 (D. Minn. 1987).

Ware v. Valley Stream High School District, 545 N.Y.S. 2d 316 (A.D. 2 Dept. 1989).

\section{Statute}

Rehabilitation Act of 1973 (codified at 29 U.S.C. sec. 701 et seq. (1988)). 
HeinOnline -- 31 Law \& Soc'y Rev. 3001997 